\title{
In vitro and in vivo Anti-Toxoplasma Effects of Allium sativum Essential Oil Against Toxoplasma gondii RH Strain
}

\author{
Sultan F Alnomasy \\ Department of Medical Laboratories \\ Sciences, College of Applied Medical \\ Sciences in Al-Quwayiyah, Shaqra \\ University, Riyadh, Saudi Arabia
}

Correspondence: Sultan F Alnomasy Email s.alnomasy@su.edu.sa
Background: Since no effective vaccine has been developed for toxoplasmosis, prophylaxis in seronegative pregnant women and immunocompromised patients with a CD4 <100 cells/ $\mu \mathrm{L}$ is highly recommended as an ideal strategy to prevent this disease. This study aimed to assess the chemical composition, in vitro, and in vivo effects of Allium sativum essential oil (ASEO) against Toxoplasma gondii RH strain.

Methods: The in vitro anti-Toxoplasma effects of different concentrations of ASEO $(32.5,75$, $150 \mu \mathrm{g} / \mathrm{mL}$ ) were measured by MTT assay for $0.5,1,2$, and $3 \mathrm{~h}$. Male Balb/c mice were orally administrated ASEO at the doses of 200, 400, and $600 \mu \mathrm{g} / \mathrm{kg} /$ day for 14 days. One day after the completion of oral drug administration, the mice in all groups were infected intraperitoneally with $1 \times 10^{4}$ tachyzoites. They were checked daily and the rate of survival was recorded. The peritoneal fluids of the mice were collected and the mean number of tachyzoites was calculated via a light microscope. The level of liver lipid peroxidation (LPO) and nitric oxide (NO), toxicity effects on the liver and kidney, and the mRNA expression levels of some pro-inflammatory cytokines such as IL- $1 \beta$ and IFN- $\gamma$ were determined by quantitative real-time PCR.

Results: Different concentrations of ASEO showed a significant $(\mathrm{p}<0.001)$ anti-Toxoplasma activity against $T$. gondii tachyzoites, and the highest efficacy was observed at the concentration of $150 \mu \mathrm{g} / \mathrm{mL}$. Fourteen days of pre-treatment of infected mice with ASEO at the doses of 200, 400 , and $600 \mu \mathrm{g} / \mathrm{kg} /$ day significantly $(\mathrm{p}<0.001)$ decreased the mean number of tachyzoites and mortality rate by the 6 th, 7 th, and 8th days after infection, respectively. ASEO at the doses of 200 , 400 , and $600 \mu \mathrm{g} / \mathrm{kg} /$ day significantly $(\mathrm{p}<0.05)$ improved the increase in the LPO and NO. Pretreatment of mice with different doses of ASEO provoked a considerable $(\mathrm{P}<0.001)$ downregulation of IL- $1 \beta$ and IFN- $\gamma$ mRNA gene expression levels, but it had no significant toxicity on the serum levels of some liver and kidney enzymes.

Conclusion: The present study demonstrated the considerable prophylactic effects of ASEO that increased the survival rate of mice and reduced the parasite load in them. Our findings also showed that ASEO promotes the innate immune system, pro-inflammatory cytokines, inhibition of hepatic injury, etc. in the mice with acute toxoplasmosis. However, additional investigations are mandatory to clarify the accurate prophylactic and therapeutic anti-Toxoplasma mechanisms of ASEO as well as all its toxicity aspects, especially in clinical settings.

Keywords: toxoplasmosis, RH strain, prophylaxis, herbal medicines, tachyzoites

\section{Introduction}

Toxoplasma gondii is a forced intracellular protozoan that causes toxoplasmosis in humans and animals worldwide. ${ }^{1}$ Acquired infections usually occur by eating raw and undercooked meat containing tissue cysts of $T$. gondii or consuming vegetables 
and water contaminated with oocysts excreted in cat feces. Congenital Toxoplasma infections occur with the placental transmission of tachyzoites in early infections during pregnancy. $^{2}$

Acquired toxoplasmosis in immunocompetent individuals occurs mainly as benign and self-limiting lymphadenopathy and rarely causes severe cerebral and ocular manifestations. ${ }^{3}$ However, the disease is an important opportunistic agent in people with impaired immune function (immunocompromised), especially in patients with AIDS and organ recipients, and is the most common cause of encephalitis in them. ${ }^{3,4}$ Toxoplasmosis is also a major congenital infection with a wide clinical spectrum, varying from neonatal asymptomatic birth to abortion, stillbirth, and birth of infants with severe cerebral and ocular complications (hydrocephalus or microcephaly, calcification and calcification). ${ }^{3,5}$

Toxoplasmosis is commonly treated with a combination of pyrimethamine and sulfadiazine and some other chemical drugs including spiramycin and atovaquone. ${ }^{6}$ Pyrimethamine is an inhibitor of the enzyme dihydrofolate reductase, which is a key enzyme in the folate synthesis pathway. Sulfadiazine is an inhibitor of the enzyme dihydropteroate, another enzyme in this pathway. ${ }^{7}$ Although the synthetic anti-Toxoplasma drugs have a good inhibitory effect on Toxoplasma, their side effects (eg, hematopoiesis disruption due to its bone marrow suppressant effect, teratogenic effects, and osteoporosis) are their main limitations. ${ }^{7,8}$

Because no effective vaccine is available to prevent toxoplasmosis, prophylaxis mainly in seronegative pregnant women and immunocompromised patients with a CD4 $<100$ cells $/ \mu \mathrm{L}$ is highly recommended as the ideal strategy to prevent the disease. ${ }^{9,10}$ Therefore, preparing an anti-Toxoplasma agent with optimal efficacy and minimal side effects is a Toxoplasma research priority.

In recent years, there has been a growing trend of research on the effectiveness of herbal products on various diseases, including parasitic diseases. ${ }^{11}$ Laboratory and experimental studies in recent years have also shown that some plant extracts and fractions exert significant antiperspirant effects against several protozoan and helminthic parasites such as Leishmania spp, Trypanosoma spp, Toxoplasma, Echinococcus spp. ${ }^{12,13}$ Allium sativum L. or garlic (Alliaceae family) has long been an important plant widely used in folk medicine worldwide. ${ }^{14}$ Garlic possesses many beneficial and pharmacological properties in traditional and modern medicine, such as anticancer, antioxidant, antidiabetic, immunomodulatory, antithrombotic, anti-fungal, antiviral, and anti-bacterial characteristics. ${ }^{15}$ The compounds in garlic are divided into two main groups of lipid-soluble allyl sulfur and water-soluble components. ${ }^{16}$ The medicinal and therapeutic properties of garlic are mainly due to the presence of sulfur-containing compounds such as allicin and other thiosulfinates. ${ }^{16}$ Garlic extract at the doses of 100, 200, 400 , and $500 \mathrm{mg} / \mathrm{kg} /$ day displayed promising therapeutic effects against acute toxoplasmosis in mice and increased the survival time and decreased the appearance of the parasite in the tissues of infected mice. ${ }^{17}$ However, the prophylactic potential of this plant's essential oil is not yet understood. Thus, the present study aimed to assess the in vitro and in vivo effects of $A$. sativum essential oil (ASEO) against $T$. gondii RH strain (tachyzoites).

\section{Materials and Methods Plant Collection}

Fresh bulbs of A. sativum were procured from a market in Riyadh, Saudi Arabia, and identified by a botanist of the Department of Biological Science, Faculty of Science and Humanities, Shaqra University, Ad-Dawadimi, Saudi Arabia. To prepare the essential oil, $200 \mathrm{~g}$ of dried and powdered rhizomes was placed in a hydro-distillation device for $180 \mathrm{~min}$ by means of a glass Clevenger-type device. The essential oil was then dehydrated by anhydrous sodium sulfate, and kept in darkness at $4^{\circ} \mathrm{C}$ in glass tubes until testing. ${ }^{18}$

\section{Gas Chromatography-Mass Spectrometry (GC-MS)}

To identify the compounds in ASEO, a Hewlett-Packard 6890 (Palo Alto, CA, USA) device equipped with an HP5MS column $(30 \mathrm{~m} \times 0.25 \mathrm{~mm}$, film thickness $0.25 \mathrm{~mm})$ was employed to perform the GC analysis. To this end, 0.1 $\mu \mathrm{L}$ of essential oil was injected into the gas chromatography apparatus and the column temperature programming $\left(225-80^{\circ} \mathrm{C}\right)$ for the separation of compounds. The percentage of essential oil constituents was also calculated. Normal C28-C8 alkanes were injected under the same conditions to calculate the inhibition index of essential oil components. Helium gas was used at a rate of $1.1 \mathrm{~mL} / \mathrm{min}$ and ionization energy of 70 electrons was used. Finally, the components of green cardamom essential oil were identified in comparison with the standard mass spectra available in the Willy-Library of the software and 
compared with the standard numbers available in references. ${ }^{19}$

\section{Parasites and Cell Culture}

T. gondii RH strain (tachyzoites) procured from King Saud University of Medical Science, Riyadh, Saudi Arabia, were maintained in $\mathrm{BALB} / \mathrm{c}$ mice via serialized intraperitoneal (IP) passages. Tachyzoites aspirated from the peritoneal cavity of the mice and were washed with phosphate-buffered saline ( $\mathrm{pH} 7.4)$, and centrifuging it for $10 \mathrm{~min}$ at $200 \mathrm{~g}$ at room temperature. This centrifugation removed host cells and debris. Subsequently, the supernatant containing the parasites was collected and centrifuged for $10 \mathrm{~min}$ at $1000 \mathrm{~g}$. The pellet was washed in two stages: first with PBS at $\mathrm{pH} 7.2$ and then with RPMI-1640 (Gibco, USA) without bovine fetal serum. In the next step, they were adjusted by a hemocytometer slide into $1 \times 10^{4}$ and $1 \times 10^{6}$ tachyzoites $/ \mathrm{mL}$ for in vivo and in vitro assays, respectively. Vero cells (ATCC No. CCL81) were cultivated in the RPMI-1640 medium with the addition of $10 \%$ inactivated fetal bovine serum (FBS), 100 units $/ \mathrm{mL}$ of penicillin, and $100 \mu \mathrm{g} / \mathrm{mL}$ of streptomycin and maintained at $37^{\circ} \mathrm{C}$ with $5 \% \mathrm{CO}_{2}$.

\section{Animal}

Seventy-two male Balb/c mice aged 6 to 8 weeks and weighing between 20 and $25 \mathrm{~g}$ were selected for this study. They were kept in appropriate conditions and temperatures with ad libitum access to food and water. The mice were handled based on the protocols for the Care and Use of Laboratory Animals provided by National Research Council (US) Committee for the Update of the Guide for the Care and Use of Laboratory Animals, Washington, D.C, USA. ${ }^{20}$ This study received the approval of the Committee on the Ethics of Animal Experiments of College of Appllied Medical Sciences in Al-Quwayiyah, Shaqra University, Saudi Arabia (SH-28-2020).

\section{In vitro Anti-Toxoplasma Effects Cell Viability Assay}

The in vitro effects of different concentrations $(32.5,75,150$ $\mu \mathrm{g} / \mathrm{mL}$ ) of ASEO against $T$. gondii tachyzoites were measured by MTT (3-(4,5-Dimethylthiazol-2-yl)-2,5-diphenyltetrazolium bromide) assay for $0.5,1,2$, and $3 \mathrm{~h}$. In brief, $0.3 \mathrm{~mL}$ of different concentrations $(32.5,75,150 \mu \mathrm{g} / \mathrm{mL})$ of ASEO were added to $0.3 \mathrm{~mL}$ of tachyzoites $\left(1 \times 10^{6}\right.$ cells $\left./ \mathrm{mL}\right)$ in sterile glass tubes which were then incubated for $0.5,1,2$, and $3 \mathrm{~h}$ at $37^{\circ} \mathrm{C}$. After this time, $0.01 \mathrm{~mL}$ of MTT $(5 \mathrm{mg} / \mathrm{mL})$ was put into the tested tubes and incubated at $37^{\circ} \mathrm{C}$ for $4 \mathrm{~h}$ with $5 \%$ $\mathrm{CO}_{2}$. Finally, $0.05 \mathrm{~mL}$ of dimethyl sulfoxide solution (Merck, Germany) was added to the combinations to dissolve the formazan crystals. The absorbance and optical density (OD) of each tested tube were calculated at $570 \mathrm{~nm}$ by ELISA reader (LX800; Biotec, USA). ${ }^{21}$ The survival rate (SR) of T. gondii was calculated as follows: \% of $\mathrm{SR}=(\mathrm{OD}$ ASO-tested wells OD blank $) /($ OD control - OD blank $) \times 100$.

\section{Effect on Infection Rate and Intracellular Parasites}

Vero cells $\left(1 \times 10^{5}\right)$ were seeded in a 96-well cell plate and incubated at $37^{\circ} \mathrm{C}$ for $24 \mathrm{~h}$. The cells were then infected with $5 \times 10^{5} T$. gondii tachyzoites per well for $24 \mathrm{~h}$. After the incubation time, the supernatant of the culture was removed, and the wells were washed twice by sterile PBS to remove cell debris. The infected cells were then exposed with ASEO at concentrations of 32.5, 75, $150 \mu \mathrm{g} /$ $\mathrm{mL}$ for $3 \mathrm{~h}$. Finally, the cells were washed and stained with Giemsa, and the prepared slides were examined under a light microscope to determine the $T$. gondii infection rate ( $\%$ of infected cells/100 examined cells) and parasite intracellular replication (mean number of parasites per cell in 100 infected cells). The 50\% inhibitory concentrations $\left(\mathrm{IC}_{50}\right)$ were also measured by the Probit test in SPSS 22. ${ }^{21}$

\section{In vivo Anti-Toxoplasma Effects}

Initially, the mice were divided into five groups, each containing 8 mice: (i) mice receiving ASEO at the dose of $200 \mu \mathrm{g} / \mathrm{kg} /$ day for two weeks; (ii) mice receiving ASEO at the dose of $400 \mu \mathrm{g} / \mathrm{kg} /$ day for two weeks; (iii) mice receiving ASEO at the dose of $600 \mu \mathrm{g} / \mathrm{kg} /$ day for two weeks; (iv) mice receiving atovaquone $100 \mathrm{mg} / \mathrm{kg} /$ day for two weeks; (v) mice treated with normal saline. Then, $24 \mathrm{~h}$ after the completion of oral drug administration, the mice in all groups were infected intraperitoneally with $1 \times 10^{4}$ tachyzoites/100 $\mu \mathrm{L}$. Finally, the mice were checked daily and the rate of survival was recorded for mice in each group. In addition, on the 3rd day postinfection, peritoneal fluids of all the mice in each group were collected, and the mean number of tachyzoites was calculated using a light microscopic. ${ }^{22}$

\section{Evaluation of Liver Lipid Peroxidation (LPO) and Nitric Oxide (NO)}

To evaluate the LPO, liver homogenates of four mice from each group on the 3rd day post-infection were examined by a biodiagnostic analysis kit based on the malondialdehyde (MDA) production using the thiobarbituric acid (TBA) methodology explained by Ohkawa et al. ${ }^{23}$ NO 
production was also measured via the hepatic suspension method described by Green et al. ${ }^{24}$

\section{Pro-Inflammatory Cytokines mRNA Expression}

The mRNA expression levels of several pro-inflammatory cytokines such as IL- $1 \beta$ and IFN- $\gamma$ were determined by quantitative real-time PCR. Briefly, total RNA was extracted from the liver tissue via an RNeasy tissue kit (Qiagen, Germany) in accordance with the manufacturer's instructions. In the next step, cDNA was synthesized using random primers for the complementary DNA (cDNA) synthesis based on the manufacturer's recommendations. Subsequently, cDNA was applied for conventional PCR reaction analysis or real-time PCR via SYBR green. The thermal profile of the reaction was $95^{\circ} \mathrm{C}$ for $5 \mathrm{~min}, 40$ cycles of $95^{\circ} \mathrm{C}$ for $10 \mathrm{~s}$ and $56^{\circ} \mathrm{C}$ for $30 \mathrm{~s}$, respectively. Finally, the $\Delta \mathrm{Ct}$ was calculated via the iQTM5 optical system software (Bio-Rad, Hercules, CA). $\beta$-actin was applied as a housekeeping gene and normalization control. Table 1 displays the oligonucleotide primers utilized for real-time PCR. ${ }^{25}$

\section{Sub-Acute Toxicity Effects of ASEO}

To determine the sub-acute toxicity effects of ASEO, 32 healthy mice were divided into four groups, each containing 8 mice: (i) healthy mice receiving ASEO at the dose of $200 \mu \mathrm{g} /$ $\mathrm{kg}$ /day for two weeks; (ii) healthy mice receiving ASEO at the dose of $400 \mu \mathrm{g} / \mathrm{kg} / \mathrm{day}$ for two weeks; (iii) healthy mice receiving ASEO at the dose of $600 \mu \mathrm{g} / \mathrm{kg} /$ day for two weeks; (iv) mice treated with normal saline. On the 15th day after the oral administration of ASEO, by cardiac puncture, blood specimens were collected from the mice via sterile syringes with and without anticoagulant (EDTA). The blood samples were then centrifuged at $3500 \mathrm{rpm}$ for $15 \mathrm{~min}$ and the separated serums were kept at $-20^{\circ} \mathrm{C}$ until testing. ${ }^{26}$ To assess the toxicity of ASEO, the serum levels of some biochemical factors related to liver and kidney function, eg, alanine aminotransferase (ALT), aspartate aminotransferase (AST), alanine aminotransferase (ALT), alkaline phosphatase (ALP),

Table I The Primers Applied for Real-Time PCR

\begin{tabular}{|l|c|c|c|}
\hline Amplicon & Primers & Sequence (5'-3') & Size (bp) \\
\hline IL-I $\beta$ & F & AACCTGCTGGTGTGTGACGTTC & 78 \\
CAGCACGAGGCTTTTTTGTTGT & \\
\hline IFN- $\gamma$ & F & ATGAACGCTACACACTGCATC & 182 \\
& R & CCATCCTTTTGCCAGTTCCTC & \\
\hline$\beta$-actin & F & $\begin{array}{c}\text { GTGACGTTGACATCCGTAAAGA } \\
\text { GCCGGACTCATCGTACTCC }\end{array}$ & 245 \\
\hline
\end{tabular}

creatinine $(\mathrm{Cr})$, and blood urea nitrogen (BUN) were measured via commercial diagnostic kits.

\section{Statistical Analysis}

All the tests were performed in triplicate and the data were represented as means \pm standard deviation. SPSS 22 (SPSS Inc., Chicago, IL, USA) was employed for data analysis. One-way ANOVA with Turkey's post-hoc test was run to assess differences among the experimental groups.

\section{Results}

The findings of GC/MS represented that 20 constituents were recognized, constituting $98.1 \%$ of the total essential oil (Table 2). The main components were diallyl disulfide (29.2\%), diallyl trisulfide (28.6\%), and allyl methyl trisulfide $(19.8 \%)$, respectively.

\section{Cell Viability Assay}

Via the MTT assay, different concentrations of ASEO displayed a significant $(\mathrm{p}<0.001)$ anti-Toxoplasma activity against $T$. gondii tachyzoites after $0.5,1,2$, and $3 \mathrm{~h}$ of incubation compared with the control group (Figure 1). The highest efficacy was observed at the concentration of $150 \mu \mathrm{g} / \mathrm{mL}$ where the mortality of tachyzoites was $100 \%$

Table 2 GC/MS Analysis of Chemical Compositions of A. sativum Essential Oil

\begin{tabular}{|c|c|c|c|}
\hline No & Compound & $\mathbf{R} \mathbf{I}^{\mathbf{a}}$ & Composition (\%) \\
\hline I. & Dimethyl disulfide & 728 & 3.1 \\
\hline 2. & Dithio-cyclopentane & 743 & 0.4 \\
\hline 3. & 2-Methylene-4-pentenal & 764 & 0.5 \\
\hline 4. & I,2-Dithiolane & 828 & 0.4 \\
\hline 5. & Diallyl sulfide & 860 & 2.2 \\
\hline 6. & Allyl (Z)-I-propenyl sulfide & 885 & 0.8 \\
\hline 7. & 3 methylthio propanol & 894 & 1.1 \\
\hline 8. & 3,4-Dimethylthiophene & 906 & 0.81 \\
\hline 9. & Allyl methyl disulfide & 908 & 0.6 \\
\hline 10. & Methyl propyl disulfide & 923 & 0.7 \\
\hline II. & Dimethyl trisulfide & 966 & 0.4 \\
\hline 12. & Diallyl disulfide & 1072 & 29.2 \\
\hline 13. & Allyl (Z)-I-propenyl disulfide & 1091 & 0.9 \\
\hline 14. & Allyl methyl trisulfide & 1128 & 19.8 \\
\hline 15. & Methyl propyl trisulfide & 1152 & 1.3 \\
\hline 16. & 2-Vinyl-4H-I,3-dithiine & 1215 & 0.7 \\
\hline 17. & Diallyl trisulfide & 1305 & 28.6 \\
\hline 18. & 5-Methyl-I,2,3,4-tetrathiane & 1356 & 0.7 \\
\hline 19. & Benzoxathiin & 1418 & 0.6 \\
\hline 20. & Diallyl tetrasulfide & 1533 & 1.3 \\
\hline \multicolumn{3}{|c|}{ Total } & 98.1 \\
\hline
\end{tabular}


after $2 \mathrm{~h}$ of incubation. Complete mortality $(100 \%)$ was also observed after $3 \mathrm{~h}$ of treatment of tachyzoites with ASEO at the concentration of $75 \mu \mathrm{g} / \mathrm{mL}$.

\section{Effect on Infection Rate and Intracellular Parasites}

The highest inhibitory effect on the infection rate was observed at the concentration of $150 \mu \mathrm{g} / \mathrm{mL}$, where the infection rate was significantly reduced $(\mathrm{p}<0.001)$ by $32.3 \%$ (Figure $2 \mathrm{~A}$ ). In addition, ASEO at the concentrations of 32.5 and $75 \mu \mathrm{g} / \mathrm{mL}$ significantly reduced $(\mathrm{p}<0.05)$ the infection rate in the T. gondii infected Vero cells by $74.3 \%$ and $53.3 \%$, respectively. Figure 2B illustrates the intracellular replication of $T$. gondii in infected Vero cells after treatment with various concentrations of ASEO. ASEO significantly decreased the mean number of intracellular parasites with $\mathrm{IC}_{50}$ of $66.9 \mu \mathrm{g} / \mathrm{mL}$, whereas this value was $72.11 \mu \mathrm{g} / \mathrm{mL}$ for atovaquone.

\section{In vivo Anti-Toxoplasma Effects}

Figure 3 depicts the in vivo anti-Toxoplasma effects of different doses of ASEO. The results represented that 14 days of pre-treatment of infected mice with ASEO at doses of 200,400 , and $600 \mu \mathrm{g} / \mathrm{kg} /$ day decreased the mortality rate by the 6th, 7th, and 8th day post-infection, respectively. The highest survival rate was observed in the mice pre-treated with ASEO at the dose of $600 \mu \mathrm{g} / \mathrm{kg} / \mathrm{day}$, where the infected mice survived three days longer than the control mice. Figure 4 also depicts the mean number of tachyzoites collected from mice in each tested group. Following pre-treatment of infected mice with ASEO at the doses of 200,400 , and $600 \mu \mathrm{g} / \mathrm{kg} / \mathrm{day}$, the mean number of tachyzoites on the 5th day was significantly reduced by $64.9 \%, 79.5 \%$, and $92.4 \%$, respectively, whereas the mean number of tachyzoites in the tested mice of the Atovaquone $100 \mathrm{mg} / \mathrm{kg}$ group was decreased by $86.7 \%$.

\section{Effect on LPO and NO}

The level of hepatic MDA and NO was significantly elevated in the $T$. gondii-infected mice treated with no drug (Figure 5); conversely, ASEO at the doses of 200, 400 , and $600 \mu \mathrm{g} / \mathrm{kg} /$ day significantly $(\mathrm{p}<0.05)$ improved this increase in the LPO and NO.

\section{Pro-Inflammatory Cytokines mRNA Expression}

Based on Figure 6, T. gondii significantly $(\mathrm{P}<0.001)$ promoted the expression level of IFN- $\gamma$ and IL- $1 \beta$ mRNA, while pre-treatment with different doses of ASEO induced a considerable $(\mathrm{P}<0.001)$ down-regulation of IL-1 $\beta$ and IFN- $\gamma$ mRNA gene expression levels.

\section{Effect on Biochemical Parameters}

Based on Figure 7, the toxicity findings revealed that pretreatment with ASEO at the doses of 200, 400, and 600 $\mu \mathrm{g} / \mathrm{kg} / \mathrm{day}$ for two weeks resulted in no mortality among the tested mice. Moreover, the findings of biochemical tests demonstrated no significant difference between these biochemical factors compared with the group treated with the ASEO and the control group $(\mathrm{P}>0.05)$.

\section{Discussion}

Since no effective vaccine has been developed to prevent toxoplasmosis, prophylaxis is highly recommended as an ideal strategy to prevent toxoplasmosis, especially in

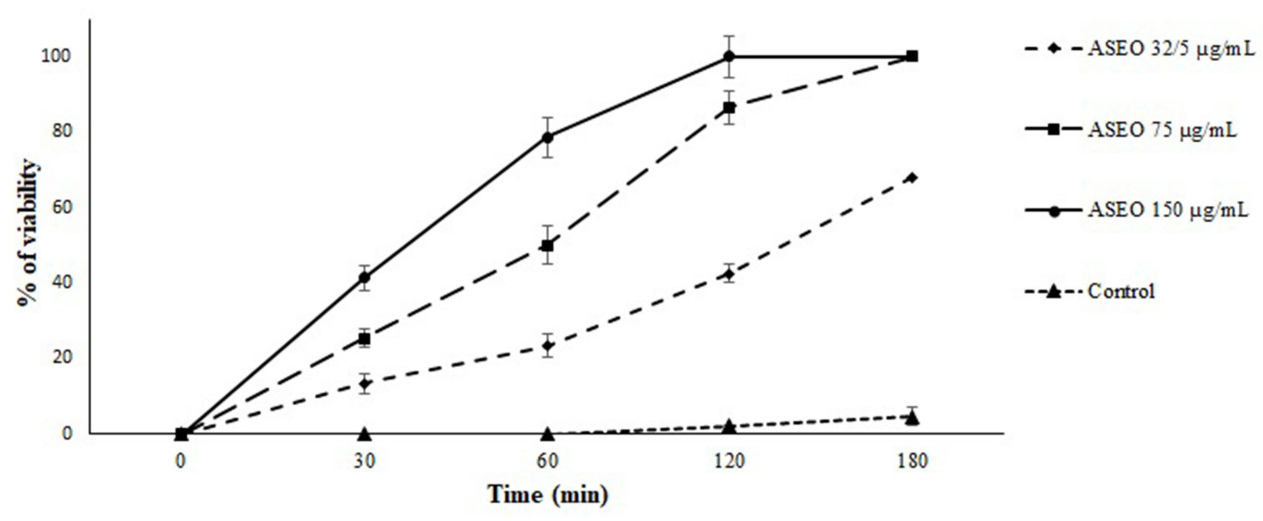

Figure I In vitro anti-Toxoplasma effects of different concentration of ASEO showed against $T$. gondii tachyzoites after 0.5 , I, 2 , and $3 \mathrm{~h}$ incubation in comparison with the control group. Data are expressed as the mean \pm SD $(n=3)$. 

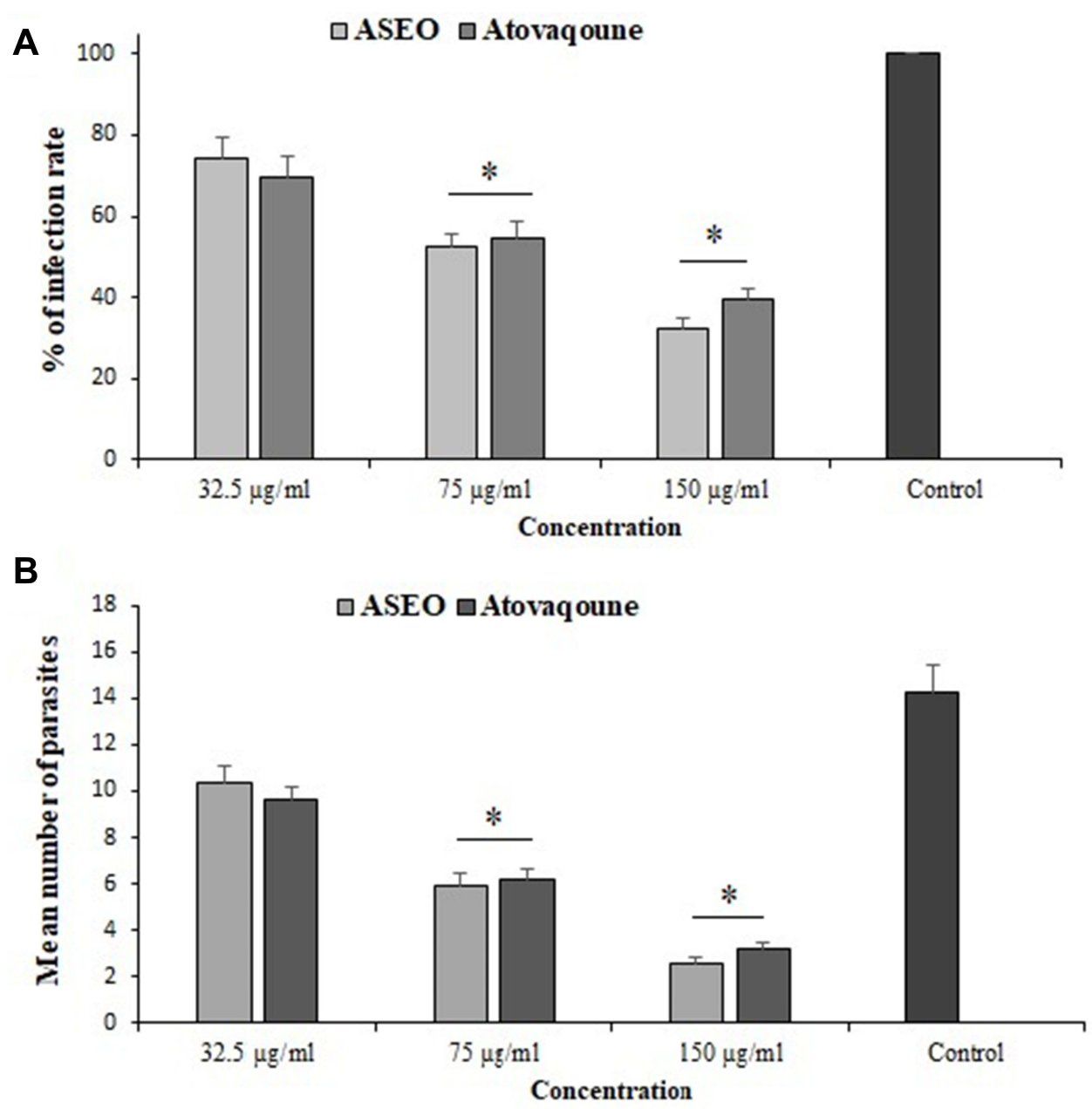

Figure 2 The infection rate of the Vero cells infected with $T$. gondii tachyzoites after exposed with Allium sativum essential oil (ASEO) at concentrations of $32.5,75$, I $50 \mu g / m l$ for $3 \mathrm{~h}$ (A). The intracellular replication of $T$. gondii in infected Vero cells after treatment with various concentrations of ASEO (B).Data are expressed as the mean \pm SD $(n=3)$. $*$ p $<0.05$.

seronegative pregnant women and immunocompromised patients with a CD4 $<100$ cells $/ \mu \mathrm{L} .{ }^{9,10}$ This study assessed the chemical composition, in vitro, and in vivo effects of A. sativum essential oil against $T$. gondii $\mathrm{RH}$ strain (tachyzoites). Our findings demonstrated that different concentrations of ASEO showed significant $(p<0.001)$ in vitro anti-Toxoplasma activity against $T$. gondii tachyzoites after $0.5,1,2$, and $3 \mathrm{~h}$ of incubation, compared with

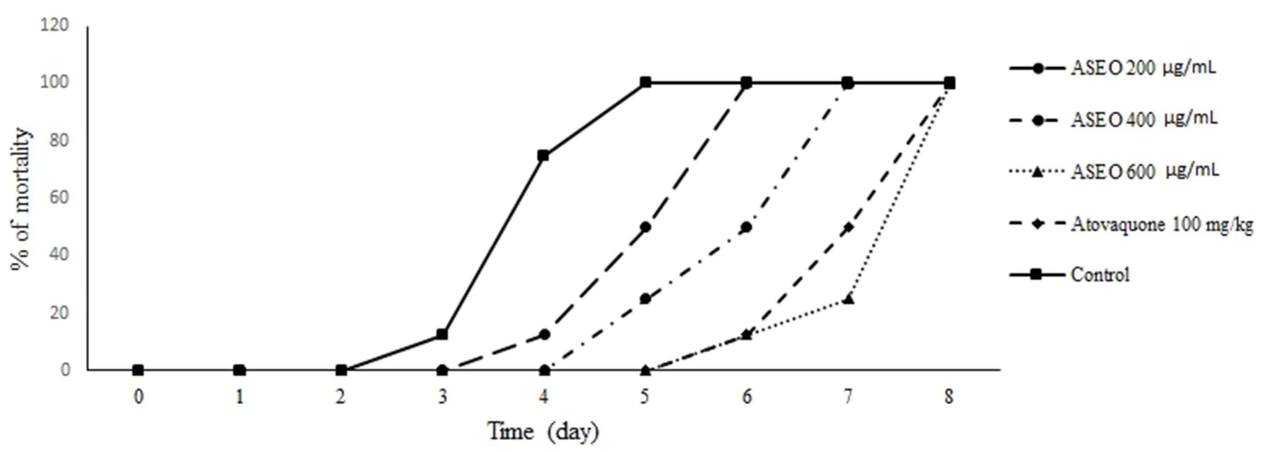

Figure 3 The mortality rate infected mice pre-treated with ASEO at the doses of 200,400 , and $600 \mu g / \mathrm{kg} /$ day for 14 days in comparison with the control group. Data are expressed as the mean $\pm S D(n=8)$. 


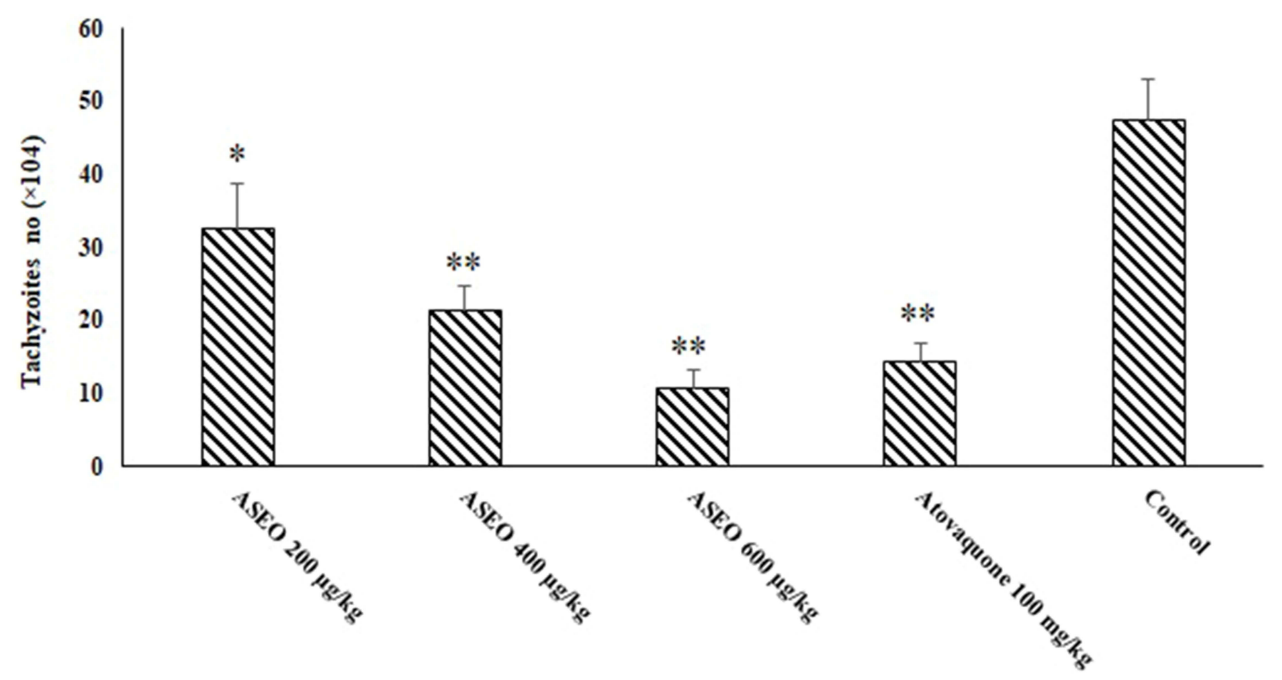

Figure 4 The mean number of tachyzoites in the infected mice pre-treated with ASEO at the doses of 200, 400 , and $600 \mu g / \mathrm{kg} / \mathrm{day}$ for 14 days. Data are expressed as the mean \pm SD $(n=8) .{ }^{*} p<0.05 ; * * 0.001$.

the control group. The highest efficacy was observed at the concentration of $150 \mu \mathrm{g} / \mathrm{mL}$ where the mortality of tachyzoites was $100 \%$ after $2 \mathrm{~h}$ of incubation. Complete mortality $(100 \%)$ was also observed after $3 \mathrm{~h}$ of treatment with ASEO at the concentration of $75 \mu \mathrm{g} / \mathrm{mL}$. As for the in vivo assay, the results represented that 14 days of pre-treatment of infected mice with ASEO at the doses of 200, 400, and $600 \mu \mathrm{g} / \mathrm{kg} /$ day decreased the mortality rate by the 6 th, $7 \mathrm{th}$, and 8th days post-infection, respectively. After pretreatment of the infected mice with ASEO at the doses of 200,400 , and $600 \mu \mathrm{g} / \mathrm{kg} / \mathrm{day}$, the mean number of tachyzoites on the 3rd day was significantly reduced by $64.9 \%, 79.5 \%$, and $92.4 \%$, respectively, whereas the mean number of tachyzoites in the tested mice of the atovaquone $100 \mathrm{mg} / \mathrm{kg}$ group was reduced by $86.7 \%$.

Considering the biological activities of $A$. sativum, previous studies have reported many beneficial and pharmacological properties for this plant in traditional and modern medicines such as anticancer, antioxidant, antidiabetic, immunomodulatory, antithrombotic, anti-fungal, antiviral, antiparasitic, anti-bacterial effects. ${ }^{14-16}$ Krstin et al have demonstrated the anti-parasitic effects of dichloromethane extract of A. sativum against Trypanosoma brucei brucei and Leishmania tarentolae with an $\mathrm{IC}_{50}(50 \%$ inhibitory concentrations) value of $0.95 \pm 0.04$ and $2.89 \pm 0.4 \mu \mathrm{g} / \mathrm{mL}$, respectively. ${ }^{27}$ Gaafar (2012) has reported the prophylactic and therapeutic efficacy of raw A. sativum juice against Cryptosporidium infection in mice where raw garlic juice reduced the cryptosporidial oocysts and intestinal lesions in infected mice. ${ }^{28}$ In the study conducted by Haji Mohammadi et al, the results showed that A. sativum methanolic extract $(10 \mathrm{~mL} / \mathrm{L})$ alone and combined with albendazole significantly reduced the number, size, and
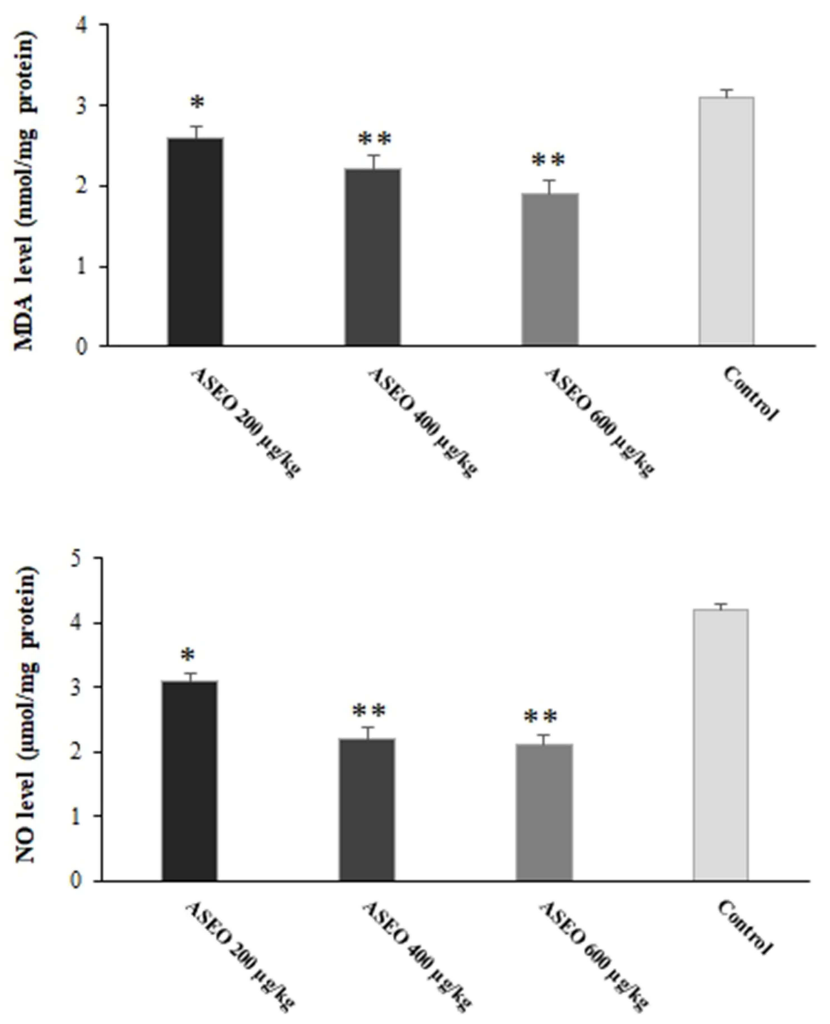

Figure 5 The level of hepatic MDA and NO in the T. gondii infected mice pretreated ASEO at the doses of 200,400 , and $600 \mu \mathrm{g} / \mathrm{kg} /$ day. Data are expressed as the mean \pm SD $(n=8)$. ${ }^{*} p<0.05 ; *^{*} p<0.001$. 

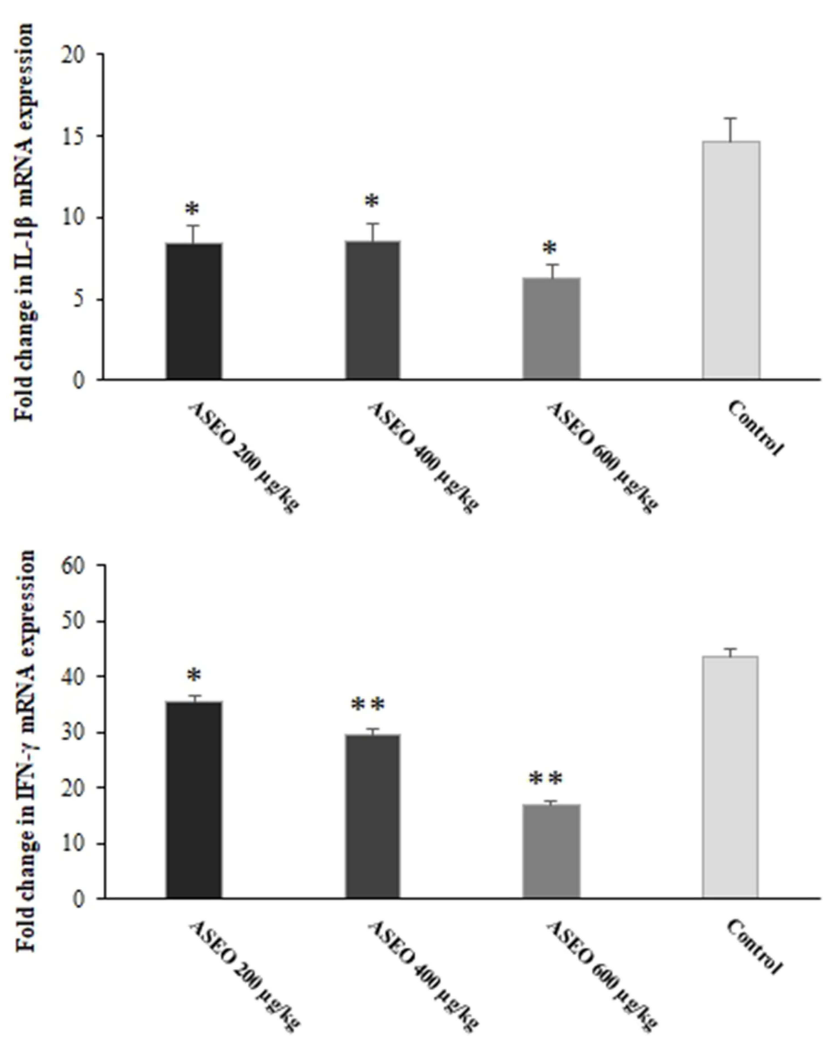

Figure 6 The expression level of IFN- $\gamma$ and IL-I $\beta$ mRNA in the T. gondii infected mice pre-treated ASEO at the doses of 200,400 , and $600 \mu \mathrm{g} / \mathrm{kg} /$ day. Data are expressed as the mean $\pm S D(n=8)$. ${ }^{*}<<0.05$; **p $<0.001$.

weight of cysts in mice experimentally infected with hydatid cyst. ${ }^{29}$ Mahmoudvand et al have demonstrated the in vitro anti-leishmanial effects of the methanolic and aqueous extracts of $A$. sativum in inhibiting the viability of $L$. tropica promastigote with $\mathrm{IC}_{50}$ values of 12.3 and $19.2 \mu \mathrm{g} / \mathrm{mL}$, respectively. ${ }^{30}$ Kinuthia et al also reported that oral administration of $A$. sativum extract significantly decreased lesion size and parasite load in the mice infected with L. major. ${ }^{31}$ In addition, Abdel-Ghaffar et al showed the in vitro and in vivo anti-helminthic effects of A. sativum against some helminthic pathogens such as Fasciola hepatica, Echinostoma caproni, Hymenolepis microstoma, Taenia taeniae formis, and $H$. diminuta. ${ }^{32}$ Zenner et al also reported the promising anti-parasitic effects of $A$. sativum essential oil against Tetratrichomonas gallinarum and Histomonas meleagridis with the minimal lethal concentration (MLC) values of 0.125 and $1 \mu \mathrm{L} / \mathrm{mL}$, respectively. ${ }^{33}$ Another study conducted by Azadbakht et al concluded that A. sativum essential oil at the concentration of $0.2 \mu \mathrm{g} / \mathrm{mL}$ significantly reduced the mortality rate of Giardia lamblia cysts and Entamoeba histolytica trophozoites by $67.4 \%$ and $83.6 \%$, respectively. ${ }^{34}$ Recently, Sidiropoulou et al have shown that A. sativum essential oil significantly inhibited the Eimeria tenella Wisconsin strain sporozoite invasion at the concentration of $100 \mu \mathrm{g} / \mathrm{mL}$ by $83 \%$ or $93 \%$ after 2 or $24 \mathrm{~h}$, respectively. ${ }^{35}$ According to Khoshzaban et al, oral treatment of murine acute toxoplasmosis with the A. sativum extract at the doses of 100, 200, 400, and $500 \mathrm{mg} / \mathrm{kg} /$ day for seven days led to a survival rate of $100 \%$ until the 5 th day of the experiment, and the Toxoplasma tachyzoites significantly vanished in the liver of the experimented mice. ${ }^{17}$

The GC/MS identified 20 constituents, constituting $98.1 \%$ of the total essential oil. The main components were diallyl disulfide (allicin, 29.2\%), diallyl trisulfide (28.6\%), and allyl methyl trisulfide (19.8\%), respectively. In consistent with our results, Satyal et al reported that the main constituents of A. sativum essential oil were diallyl trisulfide (allitridin) (33.4\%), diallyl disulfide (20.8\%), allyl methyl trisulfide (19.2\%), and allyl (E)-1-propenyl disulfide (5.2\%), respectively. ${ }^{36}$ Similarly, Dziri et al introduced diallyl trisulfide (37.3-45.9\%), diallyl disulfide (17.5-35.6\%), and methyl allyl trisulfide (7.7-10.4\%) as the chief components of $A$. sativum essential oil. ${ }^{37}$ Despite all these similarities, previous studies showed that the chemical composition of essential oils varies depending on the place where the plant grew, the part of the herbs used, the time of harvesting the herbs, and the technique of isolating the essential oil from the herbs, etc. ${ }^{38,39}$

The potent antimicrobial effects of allicin against a wide range of bacterial and parasitic pathogens such as Trypanosoma sp., Entamoeba histolytica, Giardia lamblia, Gram-positive and Gram-negative bacteria, Candida spp, etc. have been reported. ${ }^{40}$ According to Shan et al, allicin as an organosulfur compound obtained from garlic displayed high efficacy against murine acute toxoplasmosis; after treatment of infected mice with allicin alone $(30 \mathrm{mg} /$ $\mathrm{kg}$ /day) and combined with sulfamethoxazole, parasite load in the liver tissues and blood samples were significantly reduced. ${ }^{41}$

Although the exact antimicrobial mechanisms of these organosulfur compounds are not yet discovered, some studies revealed that these compounds act by disrupting DNA, RNA, and protein synthesis, reacting with sulfhydryl groups of the enzymes and proteins of microbes, damaging the cell wall and membrane, and subsequently degradation of cell membrane integrity, etc. ${ }^{42-46}$ Therefore, the anti-Toxoplasma effects of A. sativum could be due to the presence of organosulfur compounds 

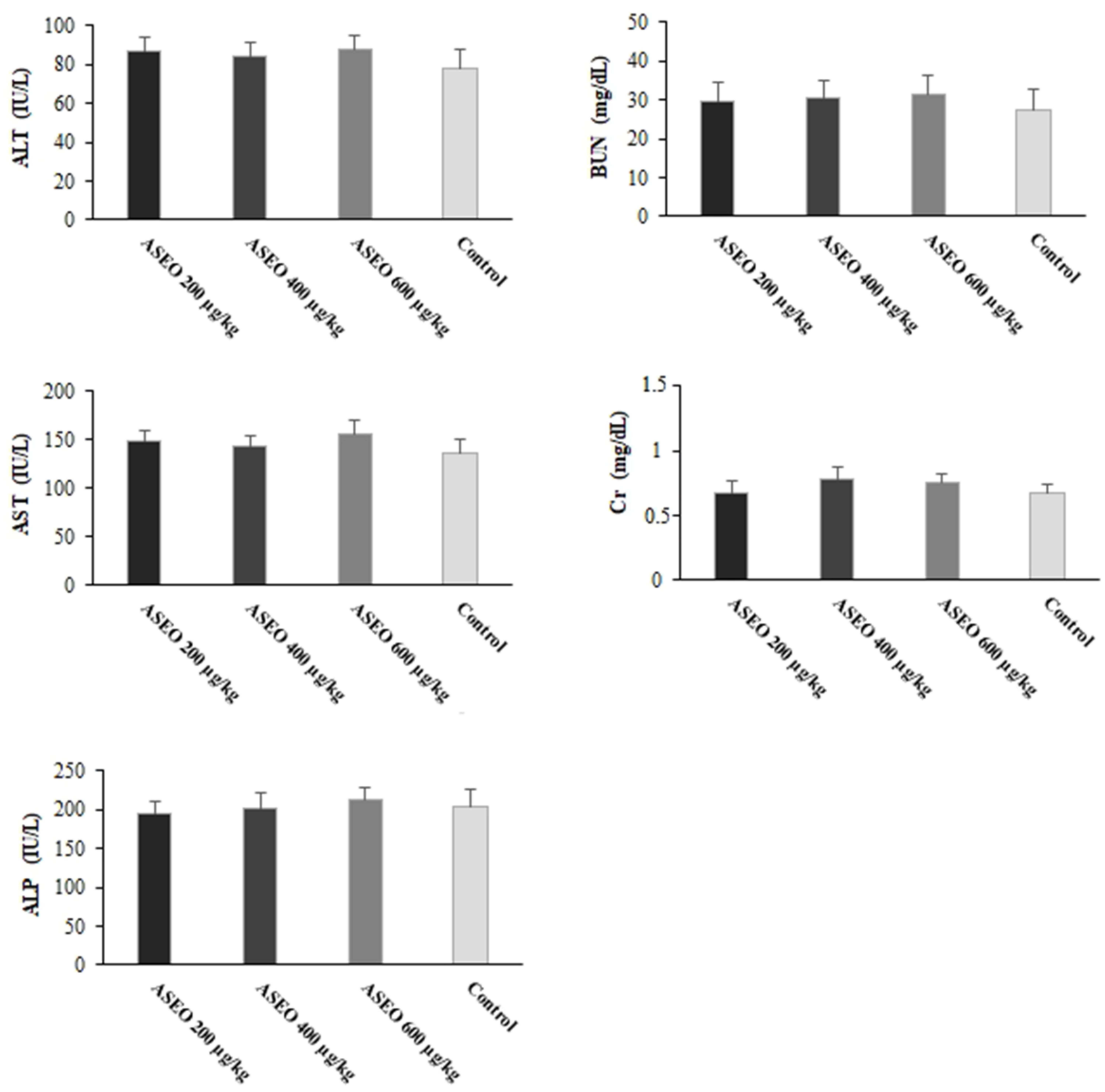

Figure 7 The level of biochemical factors in mice sera after oral administration of ASEO for 14 days. Data are expressed as the mean \pm SD $(n=8)$. Abbreviations: AST, aspartate aminotransferase; ALT, alanine aminotransferase; ALP, alkaline phosphatase; Cr, creatinine; BUN, blood urea nitrogen.

in this plant. Another mechanism that contributes to garlic's significant prophylaxis against Toxoplasma infection in mice is its immune-boosting effect. Studies confirmed that $A$. sativum strengthens the immune system, especially the cellular immune system, by stimulation of some immune cells (eg, lymphocytes, macrophages, natural killer (NK) cells), modulation of cytokine secretion, activation of macrophages, phagocytosis, production of immunoglobulins, phagocytosis, etc. ${ }^{47}$
The involvement of LPO in the pathogenesis of hepatic damage through the free radical products of $T$. gondii has been confirmed, where it causes cell membrane damage and the release of hepatotoxicity marker enzymes. ${ }^{48,49}$ Malondialdehyde (MDA) as the final product in lipid peroxidation is broadly applied as a marker for the evaluation of LPO. ${ }^{47}$ Our findings revealed that ASEO at the doses of 200, 400, and $600 \mu \mathrm{g} / \mathrm{kg} /$ day significantly $(\mathrm{p}<0.05)$ improved the rise in LPO and NO in the 
$T$. gondii infected mice. These findings can therefore show the potential mechanism whereby A. sativum acts as an anti-inflammatory drug to protect the liver.

Our real-time PCR results revealed that $T$. gondii significantly $(\mathrm{P}<0.001)$ promoted the expression level of IFN- $\gamma$ and IL- $1 \beta$ mRNA, while pre-treatment of mice with different doses of ASEO provoked a considerable $(\mathrm{P}<$ $0.001)$ down-regulation of IL-1 $\beta$ and IFN- $\gamma$ mRNA gene expression levels; this suggests that the pre-treatment of T. gondii-infected mice with $A$. sativum can prevent inflammation in them. Previous investigations reported that, in toxoplasmosis, the modulation of the production of pro-inflammatory cytokines IL- $1 \beta$, IFN- $\gamma$, etc. can prevent hypotension and enhance the host's survival upon sepsis induction. ${ }^{49}$

Nowadays, assessing the function of some vital organs such as the liver and kidneys is the main way to evaluate the toxicity of novel agents in animal experiments. ${ }^{50}$ The most common method for measuring liver and kidney function is calculating the serum levels of some liver (eg, ALT, AST, and ALP) and kidney (Cr, and BUN) enzymes. The toxicity findings revealed that pre-treatment of mice with ASEO at the doses of 200, 400, and $600 \mu \mathrm{g} / \mathrm{kg} / \mathrm{day}$ for two weeks resulted in no mortality among the tested mice. Moreover, the findings of biochemical tests demonstrated no significant difference in these biochemical factors between the group treated with ASEO and the control group.

\section{Conclusion}

Our results demonstrated the considerable prophylactic effects of ASEO, the increased survival rate of mice, and the reduced parasite load in them. Moreover, ASEO promoted the innate immune system, pro-inflammatory cytokines, hepatic injury inhibition, etc. in the mice with acute toxoplasmosis. However, more investigations are mandatory to clarify the accurate prophylactic and therapeutic anti-Toxoplasma mechanisms of ASEO as well as all its toxicity aspects, especially in clinical settings.

\section{Disclosure}

The author declares no conflict of interest for this work.

\section{References}

1. Saadatnia G, Golkar M. A review on human toxoplasmosis. Scand $J \quad$ Infect Dis. 2012;44(11):805-814. doi:10.3109/00365548.20 12.693197
2. Black MW, Boothroyd JC. Lytic cycle of Toxoplasma gondii. Microbiol Mol Biol Rev. 2000;64(3):607-623. doi:10.1128/ MMBR.64.3.607-623.2000

3. Wang ZD, Liu HH, Ma ZX, et al. Toxoplasma gondii infection in immunocompromised patients: a systematic review and meta-analysis. Front Microbiol. 2017;9(8):389.

4. Martina MN, Cervera C, Esforzado N, et al. Toxoplasma gondii primary infection in renal transplant recipients. Two case reports and literature review. Transplant Int. 2011;24(1):e6-e12. doi:10.1111/j.1432-2277.2010.01173.x

5. Hampton MM. Congenital toxoplasmosis: a review. Neonatal Netw. 2015;34(5):274-278. doi:10.1891/0730-0832.34.5.274

6. McCabe RE. Antitoxoplasma chemotherapy. In: Toxoplasmosis: A Comprehensive Clinical Guide. 2001:319-359.

7. Montazeri M, Sharif M, Sarvi S, Mehrzadi S, Ahmadpour E, Daryani A. A systematic review of in vitro and in vivo activities of anti-Toxoplasma drugs and compounds (2006-2016). Front Microbiol. 2017;8:25. doi:10.3389/fmicb.2017.00025

8. Montazeri M, Mehrzadi S, Sharif M, et al. Drug resistance in Toxoplasma gondii. Front Microbiol. 2018;9(9):2587. doi:10.3389/ fmicb.2018.02587

9. Rajapakse S, Weeratunga P, Rodrigo C, de Silva NL, Fernando SD. Prophylaxis of human toxoplasmosis: a systematic review. Pathog Glob Health. 2017;111(7):333-342. PMID: 28948861; PMCID: PMC5694886. doi:10.1080/20477724.2017.1370528

10. Derouin F, Pelloux H; ESCMID Study Group on Clinical Parasitology. Prevention of toxoplasmosis in transplant patients. Clin Microbiol Infect. 2008;14(12):1089-1101. doi:10.1111/j.1469-0691.2008.02091.x

11. Alnomasy S, Al-Awsi GR, Raziani Y, et al. Systematic review on medicinal plants used for the treatment of Giardia infection. Saudi J Biol Sci. 2021;28(9):5391-5402. doi:10.1016/j.sjbs.2021.05.069

12. Wink M. Medicinal plants: a source of anti-parasitic secondary metabolites. Molecules. 2012;17(11):12771-12791. doi:10.3390/ molecules 171112771

13. Tagboto S, Townson S. Antiparasitic properties of medicinal plants and other naturally occurring products. Adv Parasitol. 2001;50:199-295.

14. Takagi H. Garlic Allium sativum L. In: Onions and Allied Crops. CRC Press; 2020:109-146.

15. Londhe VP, Gavasane AT, Nipate SS, Bandawane DD, Chaudhari PD. Role of garlic (Allium sativum) in various diseases: an overview. Angiogenesis. 2011;12:13.

16. El-Saber Batiha G, Magdy Beshbishy A, Wasef L, et al. Chemical constituents and pharmacological activities of garlic (Allium sativum L.): a review. Nutrients. 2020;12(3):872. doi:10.3390/nu12030872

17. Khoushzaban F, Sharafi M, Ghazanfari T, Ghaffarifar F, Ghasemi Nikou S. The effect of garlic extract on acute toxoplasmosis in mice. Iranian J Med Aromat Plants. 2007;23(3):295-306.

18. Alyousif MS, Al-Abodi HR, Almohammed H, et al. Chemical composition, apoptotic activity, and antiparasitic effects of Ferula macrecolea essential oil against Echinococcus granulosus protoscoleces. Molecules. 2021;26(4):888. doi:10.3390/molecules26040888

19. Adams RP. Identification of Essential Oil Components by Gas Chromatography/Mass Spectroscopy. Illinois, IL, USA: Allured Publishing Corporation; 2004.

20. National Research Council (US) Committee for the Update of the Guide for the Care and Use of Laboratory Animals. Guide for the Care and Use of Laboratory Animals. Washington (DC): National Academies Press (US); 2011.

21. Teimouri A, Jafarpour Azami S, Keshavarz H, et al. Anti-Toxoplasma activity of various molecular weights and concentrations of chitosan nanoparticles on tachyzoites of RH strain. Int $J$ Nanomedicine. 2018;13:1341-1351. doi:10.2147/IJN.S158736

22. Shakibaie M, Ezzatkhah F, Gabal E, Badparva E, Jahanbakhsh S, Mahmoudvand $H$. Prophylactic effects of biogenic selenium nanoparticles on acute toxoplasmosis: an in vivo study. Ann Med Surg. 2020;54(54):85-88. doi:10.1016/j.amsu.2020.04.010 
23. Ohkawa H, Ohishi N, Yagi K. Assay for lipid peroxides in animal tissues by thiobarbituric acid reaction. Anal Biochem. 1979;95 (2):351-358. doi:10.1016/0003-2697(79)90738-3

24. Green LC, Wagner DA, Glogowski J, Skipper PL, Wishnok JS, Tannenbaum SR. Analysis of nitrate, nitrite, and $[15 \mathrm{~N}]$ nitrate in biological fluids. Anal Biochem. 1982;126(1):131-138. doi:10.1016/ 0003-2697(82)90118-X

25. Shaapan RM, Al-Abodi HR, Alanazi AD, et al. Myrtus communis essential oil; anti-parasitic effects and induction of the innate immune system in mice with Toxoplasma gondii infection. Molecules. 2021;26(4):819. doi:10.3390/molecules26040819

26. Shakibaie M, Shahverdi AR, Faramarzi MA, Hassanzadeh GR, Rahimi HR, Sabzevari O. Acute and subacute toxicity of novel biogenic selenium nanoparticles in mice. Pharm Biol. 2013;51 (1):58-63. doi:10.3109/13880209.2012.710241

27. Krstin S, Sobeh M, Braun MS, Wink M. Anti-parasitic activities of Allium sativum and Allium cepa against Trypanosoma b. brucei and Leishmania tarentolae. Medicines. 2018;5(2):37. PMID: 29690511; PMCID: PMC6023319. doi:10.3390/medicines5020037

28. Gaafar MR. Efficacy of Allium sativum (garlic) against experimental cryptosporidiosis. Alexandria J Med. 2012;48(1):59-66. doi:10.1016/ j.ajme.2011.12.003

29. Haji Mohammadi KH, Heidarpour M, Borji H. Allium Sativum Methanolic extract (garlic) improves therapeutic efficacy of Albendazole against hydatid cyst: in vivo study. J Invest Surg. 2019;32(8):723-730. doi:10.1080/08941939.2018.1459967

30. Mahmoudvand H, Sepahvand P, Jahanbakhsh S, Azadpour M. Evaluation of the antileishmanial and cytotoxic effects of various extracts of garlic (Allium sativum) on Leishmania tropica. J Parasit Dis. 2016;40(2):423-426. PMID: 27413315; PMCID: PMC4927502. doi:10.1007/s12639-014-0520-9

31. Kinuthia GK, Kabiru EW, Anjili CO, et al. Efficacy of crude methanolic extracts of Allium sativum L. and Moringa stenopetala (Baker f.) Cufod. against Leishmania major. Int J Med Arom Plants. 2014;4 (1): $16-25$.

32. Abdel-Ghaffar F, Semmler M, Al-Rasheid KA, et al. The effects of different plant extracts on intestinal cestodes and on trematodes. Parasitol Res. 2011;108(4):979-984. doi:10.1007/s00436-0102167-5

33. Zenner L, Callait MP, Granier C, Chauve C. In vitro effect of essential oils from Cinnamomum aromaticum, Citrus limon and Allium sativum on two intestinal flagellates of poultry, Tetratrichomonas gallinarum and Histomonas meleagridis. Parasite. 2003;10(2):153-157. doi:10.1051/parasite/2003102153

34. Azadbakht M, Saeedi Akbarabadi A, Motazedian MH, Monadi T, Akbari F. Anti-parasitic activity of some medicinal plants essential oils on Giardia lamblia and Entamoeba histolytica, in vitro. Res J Pharmacogn. 2020;7(1):41-47.

35. Sidiropoulou E, Skoufos I, Marugan-Hernandez V, et al. In vitro anticoccidial study of oregano and garlic essential oils and effects on growth performance, fecal oocyst output, and intestinal microbiota in vivo. Front Vet Sci. 2020;7(7):420. doi:10.3389/fvets.2020.00420

36. Satyal P, Craft JD, Dosoky NS, Setzer WN. The chemical compositions of the volatile oils of garlic (Allium sativum) and wild garlic (Allium vineale). Foods. 2017;6(8):63. PMID: 28783070; PMCID: PMC5575638. doi:10.3390/foods6080063
37. Dziri S, Casabianca H, Hanchi B, Hosni K. Composition of garlic essential oil (Allium sativum L.) as influenced by drying method. J Essent Oil Res. 2014;26(2):91-96. doi:10.1080/ 10412905.2013.868329

38. Dhifi W, Bellili S, Jazi S, Bahloul N, Mnif W. Essential oils' chemical characterization and investigation of some biological activities: a critical review. Medicines. 2016;3:25. doi:10.3390/ medicines 3040025

39. Saedi Dezaki E, Mahmoudvand H, Sharififar F, Fallahi S, Monzote L, Ezatkhah F. Chemical composition along with anti-leishmanial and cytotoxic activity of Zataria multiflora. Pharm Biol. 2016;54 (5):752-758

40. Lun ZR, Burri C, Menzinger M, Kaminsky R. Antiparasitic activity of diallyl trisulfide (Dasuansu) on human and animal pathogenic protozoa (Trypanosoma sp., Entamoeba histolytica and Giardia lamblia) in vitro. Ann Soc Belg Med Trop. 1994;74(1):51-59. PMID: 8024350

41. Shan LY, Yang XZ, Liu PM. [PCR in evaluating the effect of allicin and its combination with SMZco on murine toxoplamosis]. Zhongguo Ji Sheng Chong Xue Yu Ji Sheng Chong Bing Za Zhi. 2003;21 (4):203-206. Chinese. PMID: 14628365.

42. Nakamoto M, Kunimura K, Suzuki JI, Kodera Y. Antimicrobial properties of hydrophobic compounds in garlic: allicin, vinyldithiin, ajoene and diallyl polysulfides. Exp Ther Med. 2020;19 (2):1550-1553.

43. Ankri S, Mirelman D. Antimicrobial properties of allicin from garlic. Microbes Infect. 1999;1(2):125-129. PMID: 10594976. doi:10.1016/ s1286-4579(99)80003-3

44. Sagdic O, Tornuk F. Antimicrobial properties of organosulfur compounds. In: Dietary Phytochemicals and Microbes. Dordrecht: Springer; 2012:127-156.

45. Bhatwalkar SB, Mondal R, Krishna SB, Adam JK, Govender P, Anupam R. Antibacterial properties of Organosulfur compounds of garlic (Allium sativum). Front Microbiol. 2021;12:613077.

46. Arreola R, Quintero-Fabián S, López-Roa RI, et al. Immunomodulation and anti-inflammatory effects of garlic compounds. J Immunol Res. 2015;2015:401630. PMID: 25961060; PMCID: PMC4417560. doi:10.1155/2015/401630

47. Alajmi RA, AL-Megrin WA, Metwally D, et al. Anti-Toxoplasma activity of silver nanoparticles green synthesized with Phoenix dactylifera and Ziziphus spina-christi extracts which inhibits inflammation through liver regulation of cytokines in Balb/c mice. Biosci Rep. 2019;39(5):BSR20190379. doi:10.1042/BSR20190379

48. Nolan SJ, Romano JD, Kline JT, Coppens I. Novel approaches to kill Toxoplasma gondii by exploiting the uncontrolled uptake of unsaturated fatty acids and vulnerability to lipid storage inhibition of the parasite. Antimicrob Agents Chemother. 2018;62(10):e00347e00418. doi:10.1128/AAC.00347-18

49. Souza MC, Fonseca DM, Kanashiro A, et al. Chronic toxoplasma gondii infection exacerbates secondary polymicrobial sepsis. Front Cell Infect Microbiol. 2017;7:116. doi:10.3389/fcimb.2017.00116

50. Yang M, Wu Z, Wang Y, et al. Acute and subacute toxicity evaluation of ethanol extract from aerial parts of Epigynum auritum in mice. Food Chem Toxicol. 2019;131(131):110534. doi:10.1016/j. fct.2019.05.042 


\section{Publish your work in this journal}

Infection and Drug Resistance is an international, peer-reviewed openaccess journal that focuses on the optimal treatment of infection (bacterial, fungal and viral) and the development and institution of preventive strategies to minimize the development and spread of resistance. The journal is specifically concerned with the epidemiology of antibiotic resistance and the mechanisms of resistance development and diffusion in both hospitals and the community. The manuscript management system is completely online and includes a very quick and fair peerreview system, which is all easy to use. Visit http://www.dovepress.com/ testimonials.php to read real quotes from published authors.

Submit your manuscript here: https://www.dovepress.com/infection-and-drug-resistance-journal 